\title{
特別講演
}

\author{
蒾科心身症の臨床 \\ 一器質的所見にそしい患者をどうみるかー

\section{Psychosomatics in Dental Clinics: A Viewpoint of Psychiatry}

\author{
○黒木俊秀 \\ Toshihide Kuroki \\ 九州大学大学院医学研究院精神病態医学分野 \\ Department of Neuropsychiatry, Kyushu University Graduate School of Medical Sciences
}

\section{I. 歯科心身症とは？}

口腔という器官は，味覚をはじめ極めて繊細な知覚器 が分布し，食物の摂取という生命の維持に不可欠の機能 を担い，かつ言語や表情のコミュニケーションに重要な 役割を果たし，それはエロスの表出にも関わる。以上の ように，口腔には人間の内界と外界をつなぐ多彩な機能 が集中するために，そこには身体のみならず精神内界の 変化が反映されやすい。

実際, 様々な口腔内の症状を訴えて受診するが, 器質 的異常所見を発見できないか, 発見できてもその所見で は説明できず，（かつ患者は真剣に訴えるために）歯科 医や口腔外科医を当惑させる症例は少なくない。それら は, 歯科口腔外科領域では, 口腔異常感症, 舌痛症, 非 定型顔面痛, 顎関節症, 義歯不適応症等々, と呼ばれて いる。一方，これらは，恐らくはなんらかの心因性の機 能障害であろうと推測されて「歯科心身症」と総称され ることがある。ところが, この名称自体が臨床の現場で は混乱を生じかねない。というのも, 狭義の心身症とは 「器質的病変を有するか, あるいは病態生理が明らかな 身体疾患でその病像が心理的社会的要因の影響を受けや すい病態」をいうが，そのような症例は実は歯科口腔外 科領域では稀である。むしろ，現実には「歯科心身症」 症例の多くは器質的所見を欠き, その基礎には精神医学 的にうつ病, 不安障害, 老年痴呆, 統合失調症などの精 神障害が潜在している可能性が高い2)。したがって，歯 科心身症とは「歯科口腔外科領域における, とくに心理 面からのアプローチが重要な意味を持つ病態」と大まか
に定義するのが良いだろう。すなわち，器質的所見にそ しい歯科口腔外科領域の症状には, 心身医学・精神医学 的なアプローチが必要とされることを意味している。本 講演では, 症例を呈示し歯科心身症に対する精神医学的 診断と治療について解説したい。

\section{II. 症例提示}

症例 $1 ： 39$ 歳，女性

主 訴: 㚘部痛

現病歷：34歳頃, 左鼻翼付近に鈍痛を自覚。歯疾と考 え，バファリンを服用していたが，痛みが徐々に増強。 朝, 起床した途端に痛みが始まる。歯科医を転々とする が, どこでも異常はないと云われた。歯根切除術, 掻破 術, レーザー治療なども受けたが無効であった。歯痛に 対して「ナロン」（ブロムワレリル尿素含有）を服用す るうちに，同薬に対する依存を形成した。39歳，ナロン 依存症の治療を勧められ, 精神科を受診。入院しナロン 乱用は止まったが，上顎の痛みは軽減しなかった。面接 では,「歯科の先生は何もないというけれど, 確かにな にか異常があると思う。その証拠に時々出血する。と 述へ, 疾病の確信は強い。抑うつ感は乏しい。

[考察] 本症例は, 歯疾にかかっているという観念への とらわれが強固で, 歯科医師の説明にもかかわらず頑固 に持続している。うつ病は伴っておらず心気症 ${ }^{1)}$ と診 断されるが，こうした症例ではしばしば鎮痛剤をはじめ として薬物に対する依存傾向を伴うことがある。自分に は精神科治療は必要ないと考えるため, 治療関係を結ぶ 
ことが難しい。

症例 $2: 56$ 歳, 女性

主 訴：歯が硬くなる

現病歴: 54 歳, 抑うつ気分, 不眠が出現。精神科にて うつ病と診断され薬物療法を開始された。55歳, 左上 顎の歯茎に硬い感じが生じ, 歯科医院を受診したが, 異 常は認められなかった。精神科から数種類の抗うつ薬を 処方されたが, 効果に乏しく, 大学病院を紹介された。

表情硬く眉間にしわを寄せて苦しそうに訴える。「朝 起きると左の歯茎に硬い感じがあって, 歯ぎしりしてい ます。鉄みたいにガチガチという音がして気持ちが悪く てたまりません。このまま治らなければ死んだほうがま しです。以前は左側だけだったのに最近は右側の歯茎も 硬くなります。」訴えは頑固で訂正されない。歯茎の異 常知覚のほかにも不眠や食思不振を過剩に心配し悲観す る。すべての動作が重苦しくゆっくりしている。一日中, 自宅にひきこもり，何も手がつかないでいる。趣味にも 全く興味が向かない。

[考察] 本症例は, うつ病の経過中に口腔内の知覚異常 を呈したもので, 器質的異常では説明できない, かくも 奇妙な（しばしばグロテスクな），しかし患者自身にとっ ては不快極まりない知覚異常は「口腔内セネストパチー (体感幻覚)」と呼ばれる。セネストパチーは, 統合失調 症, うつ病, 老年痴呆等の随伴症状としてみられる場合 があり，その場合は基礎疾患の治療が主体となるが, 一 般に難治性で慢性化しやすい。本症例は, 基底にはうつ 病の存在が疑われたため, 十分な用量の抗うつ薬を投与 したところ, 症状の改善が認められた。

症例 $3: 67$ 歳, 女性

主 訴：歯がガチガチしてものを食べられない

現病歴: 57 歳, 不眠, 倦怠感, 抑うつ気分が出現。初老 期うつ病の診断にて精神科で入院治療を受けた。退院後, 外来通院していたが，62歳頃より歯痛を訴え，歯科受診 したが異常は認められなかった。65歳, 倦总感, 焦燥感, 希死念慮が強くなり,「歯にものが詰まっている」といっ てバナナと日本酒しか口にしない時期もあった。67歳, 上記主訴を悲観して自殺未遂あり, 再入院。しきりに口 をモグモグ, ピチャピチャいわせている。表情険しく, 動作や会話に柔らかさがなく, つっけんどんで唐突に話 し始める。
表 1. 歯科心身症の分類 ${ }^{2)}$

(括弧内は歯科口腔外科領域の診断)

I . 実際には存在しない身体疾患の確信（口臭症, 癌恐怖症, 醜形恐怖症)

II. 他覚的所見に見合わない知覚異常（舌痛症, 非定型顔面痛, 口腔異常感症, 顎関節症 $\mathrm{V}$ 型, 義歯不適応症）

III. a ) 随意筋の運動障害（開口障害, 顎関節症 I 型の一部)

b ) 自律神経系を介した機能障害 (治療恐怖症, デンタルショック)

IV. 器質的変化, 病態生理の明らかな身体疾患（顎 関節症 II ・ III IV 型の一部, 再発性アフタ, 地図状舌の一部)

頭部MRI検査では，前頭～側頭葉に優位な大脳皮質の 萎縮を認め, SPECTでも同部位の血流低下を認めた。神 経心理学的検査は, 明らかな記銘力低下と保続傾向を示 した。

[考察] 本症例も, 最初はうつ病に伴う口腔内セネスト パチーと考えられたが, その後の経過と検査所見は前頭 側頭型痴呆の可能性を示唆している。脳器質的病変に関 連した口腔内セネストパチーの報告は多い。

\section{III. 歯科心身症の精神医学的診断}

宮岡 ${ }^{2)}$ は, いわゆる歯科心身症を, その病態から表 1のように分類しているが, 精神医学的アプローチの違 いに対応しており, 臨床上, 有用である。このうち， I と IIが精神医学的にはうつ病や統合失調症, 身体表現性 障害 ${ }^{1)}$ に対応し, II と V は は不安障害, および狭義の心 身症に対応する可能性が高い。

一般に，(1)女性，(2)睡眠障害や食欲低下，体重減少な どの随伴症状, (3)朝方の症状悪化, (4)心理的ストレスの 関与が認められる症例は, うつ病が疑われることが多く, 抗うつ薬が奏功することが少なくない。

\section{N. 文献}

1) 黒木俊秀: 身体表現性障害と抑うつ. 臨床精神薬理 $6: 1445-1451,2003$

2 ) 宮岡等ほか: 心身症概念と「歯科心身症」の臨床分 類をめぐって．日歯心身 $4: 28-32 ， 1989$ 